\title{
Perbaikan Kinerja Guru Madrasah Ibtidaiyah: Pelatihanan, Perancangan, dan Pendampingan
}

\author{
Muhammad Yaumi*
}

\begin{abstract}
The purposes of this study were to increase teachers' understanding of multiple intelligences through learner-centered approach, improve teachers' performance in designing learner characteristics-oriented instruction, and improve teachers' performance in implementing instruction. This study used action research by using proactive design involving 26 respondents from 10 elementary Madrasah in Gowa, South Sulawesi and 4 collaborators. The methods of data collection were observation, interview, and test. The collected data were analyzed by using a mixed method (qualitative and quantitative). The results showed that the implementation of training on multiple intelligence based learning proved to increase teachers' understanding of learner centered approach and contribute an average score $32.61 \%$ of teachers' performance improvement, designing multiple intelligences based learning proved to give a contribution of $26.55 \%$ to the teachers' performance improvement, and mentor system proved to give contribution of $23,86 \%$ to the teachers' performance improvement in instructional implementation. It is suggested that the implementation of training should be followed by workshop and training in order to increase teachers' performance.
\end{abstract}

Keywords: teacher's performance, multiple intelligences, training, designing, mentoring

\begin{abstract}
Abstrak: Tujuan penelitian ini untuk meningkatkan pemahaman guru tentang pembelajaran berbasis kecerdasan jamak melalui pendekatan berbasis pada peserta didik, memperbaiki kinerja guru dalam mendesain pembelajaran yang berorientnasi pada karakteristik peserta didik, dan memperbaiki kinerja guru dalam pelaksanaan pembelajaran. Penelitian ini menggunakan metode penelitian tindakan menerapkan desain proaktif dengan melibatkan 26 responden dari 10 Madrasah Ibtidaiyah di kabupaten Gowa Sulawesi Selatan dan 4 orang kolaborator. Pengumpulan data menggunakan observasi, interviu, dan tes yang dianalisis dengan menggunakan mixed method (kualitatif dan kuantitatif). Hasil penelitian menunjukkan bahwa pelaksanaan pelatihan tentang pembelajaran berbasis kecerdasan jamak terbukti dapat meningkatkan pemahaman guru tentang pembelajaran berbasis pada peserta didik dan berkontribusi rata-rata sebesar $32.61 \%$ dalam perbaikan kinerja guru, desain aktivitas pembelajaran berbasis kecerdasan jamak terbukti memberi kontribusi sebesar $26.55 \%$ bagi peningkatan kinerja guru dalam perencanaan pembelajaran, dan pelaksanaan pendampingan terbukti memberi berkontribusi sebesar 23,86\% bagi perbaikan kinerja guru dalam pelaksanaan pembelajaran. Untuk meningkatkan kinerja guru diperlukan pelaksanaan pelatihan, workshop (desain pembelajaran), dan pendampingan.
\end{abstract}

Kata Kunci: kinerja Guru, kecerdasan jamak, pelatihan, perencanaan, pendampingan

\section{PENDAHULUAN}

Perbaikan kinerja guru menjadi kajian

yang banyak diminati beberapa tahun terakhir

ini. Berbagai perspektif telah digunakan untuk mendekati kajian ini. Ditinjau dari perspektif wawasan kependidikan, proses, dan evaluasi pembelajaran, kompetensi guru-guru madrasah belum menunjukkan hasil yang maksimal. Hasil

*Pascasarjana Universitas Islam Negeri Alauddin Makassar, email: muhammadyaumi@gmail.com, HP.085217720664 
studi yang dilakukan oleh Taruna (2011) menemukan bahwa kompetensi profesional guru kurang baik, wawasan kependidikan sangat rendah, dan penguasaan proses belajar rendah, namun sangat menguasai bahan pembelajaran. Hasil penelitian Hurmaini (2011) juga menunjukkan bahwa sekitar 61,67\% guru yang sudah sertifikasi pada Madrasah Tsanawiyah Negeri (MTsN) Kota Jambi memiliki tingkat kinerja dalam proses pembelajaran berada pada kategori sedang. Kondisi ini dibarengi dengan sekitar 59, 17\% tingkat pelaksanaan sertifikasi guru, dan sekitar 61, 67\% motivasi berprestasi mereka yang juga sedang.

Penelitian lain dilakukan oleh Khodijah (2016) melihat dari indikator perencanaan, pelaksanaan, penilaian pembelajaran, dan pengembangan profesi, rata-rata masih berada di bawah standar minimum kinerja. Hasil temuannya menunjukkan bahwa tidak terdapat perbedaan kinerja setelah memperoleh tunjangan profesional melalui program sertifikasi guru baik antara guru madrasah dan guru PAIS di sekolah umum, antara guru yang tinggal di lingkungan perkotaan dan guru yang tinggal di pedesaan, dan antara guru yang yang lulus sertifikasi melalui jalur portofolio dan guru yang lulus melalui jalur Pendidikan dan Pelatihan Profesi Guru (PLPG).

Kondisi kinerja guru madrasah dari hasil temuan di atas berbanding terbalik dengan besarnya komitmen pemerintah Indonesia dalam upaya perbaikan kinerja guru beberapa tahun terakhir ini. Lahirnya undang-undang nomor 20 Tahun 2003 tentang Sistem Pendidikan Nasional yang mengakui tenaga pendidik sebagai tenaga profesional, UndangUndang Nomor 14 Tahun 2005 tentang Guru dan
Dosen, dan Peraturan Menteri (PERMEN) Pendidikan Nasional Republik Indonesia Nomor 10 Tahun 2009 tentang Sertifikasi Guru dalam Jabatan merupakan bukti menguatnya komitmen untuk meningkatkan kinerja tenaga pendidik.

Nampaknya, ada sesuatu yang keliru tentang upaya perbaikan kinerja guru yang dilaksanakan melalui program sertifikasi yang menitikberatkan pada pengumpulan portofolio, berkembang menjadi Pendidikan dan Latihan Profesi Guru (PLPG), kemudian diformulasi dalam bentuk Pendidikan Profesi Guru (PPG). Program yang terakhir ini mulai diterapkan pada tahun 2015 (Hotimah, 2017). Program PPG dipandang sebagai solusi dari berbagai kelemahan dari penyelenggaraan portofolio dan PLPG. Namun, sebagian praktisi pendidikan memandang juga bahwa program PPG tidak akan mampu memberi pengaruh signifikan terhadap peningkatan kinerja guru sesuai yang diharapkan.

Terdapat empat indikator utama yang dipandang sebagai titik kelemahan program ini. Pertama, pola pembelajaran berorientasi teoretis padahal yang dibutuhkan oleh guru adalah praktik terbaik dalam mendesain dan melaksanakan pembelajaran. Kedua, durasi waktu yang relatif pendek padahal terdapat puluhan mata kuliah yang ditawarkan. Ketiga, tidak terjadi keber-lanjutan proses belajar setelah program selesai yang menyebabkan motivasi belajar guru menjadi menurun. Keempat, program tidak dirancang sampai pada tingkat pendampingan di dalam ruang kelas yang menyebabkan guru mengalami kesulitan untuk menjembatani kesesuaian antara teori yang dipelajari di perguruan tinggi dengan 
kondisi nyata di lapangan.

Menyadari beberapa kelema-han program peningkatan kinerja guru madrasah baik yang dilaksanakan melalui portofolio, PLPG maupun yang akan dilaksanakan melalui program PPG, maka dipandang perlu untuk melaksanakan perbaikan kinerja guru melalui pelatihan, perancangan, dan pendampingan tentang pembelajaran berbasis kecerdasan jamak. Pelatihan yang diikuti dengan pendampingan berkontribusi positif terhadap perbaikan dan konsistensi kinerja guru dalam pelaksanaan pembelajaran (Harris \& Sass, 2011). Pendampingan formal dan informal berkorelasi positif dengan dukungan psikologis individu dan pengembangan karir profesional guru (Ismail, Abdullah, \& Francis, 2009).

Selanjutnya, pemberian pelatihan tentang berbagai cara terbaik untuk belajar dan mengembangkan kecerdasan peserta didik melalui pembelajaran berbasis Multiple Intelligences (MI), diterjemahkan menjadi kecerdasan jamak, kecerdasan ganda, atau kecerdasan banyak dalam bahasa Indonesia merupakan langkah strategik untuk menerapkan pembelajaran berdiferensiasi dan demokratis. Kondisi objektif di lapangan menunjukkan bahwa identifikasi dan penggalian kecerdasan peserta didik masih sangat jarang dijadikan sandaran utama mengawali setiap pembelajaran. Kecenderungan, minat, bakat, talenta, dan keterampilan dasar belum menjadi bagian yang integral dalam pengembangan kurikulum dan pembelajaran sehingga dapat mengakomodasi dan memfasilitasi terbangunnya suatu pola pembinaan yang mengedepankan tumbuh dan berkembangnya kecerdasan jamak.
Berdasarkan fenomena aktual seperti dijelaskan di atas, maka permasalahan umum yang menjadi fokus kajian ini adalah bagaimana memperbaiki kinerja guru Madrasah Ibtidaiyah melalui pelatihan, desain, dan pendampingan pembelajaran ber-basis kecerdasan jamak? Secara khusus, permasalahan kajian ini dapat dijabarkan seperti (1) bagaimana kontribusi pelak-sanaan pelatihan tentang pembelajaran berbasis kecerdasan jamak terhadap kinerja guru Madrasah Ibtidaiyah Kabupaten Gowa Sulawesi Selatan? (2) bagaimana kinerja guru Madrasah Ibtidaiyah Kabupaten Gowa Sulawesi Selatan setelah pelaksanaan workshop desain pembelajaran secara kolaboratif? (3) bagaimana perbaikan kinerja guru melalui pendampingan pelaksanaan pembelajaran? Hasil penelitian ini bermanfaat masing-masing bagi (1) para pengambil kebijakan dalam pengembangan kurikulum dan penentuan pola pengembangan profesionalisme guru, (2) kepala sekolah dalam pelaksanaan supervisi pendidikan, (3) guru dalam perencanaan dan pelaksanaan pembelajaran, dan (4) peneliti dalam mengembangkan kawasan keilmuan dan penelitian dalam bidang ilmu pendidikan.

Perbaikan kinerja dalam kajian teknologi pendidikan dapat dipahami melalui definisi teknologi pendidikan yang diberikan oleh Association for Educational Communication and Technology (AECT) seperti yang dikutip oleh Januszewski \& Molenda (2013) yang mengatakan bahwa teknologi pendidikan adalah studi dan praktik etis untuk menfasilitasi belajar dan memperbaiki kinerja dengan menciptakan, menggunakan, dan mengelola proses dan sumber teknologi yang sesuai). 
Improving performance (mem-perbaiki kinerja) dalam definisi tersebut dipandang sebagai upaya untuk meningkatkan efektivitas dan efisiensi yang mengarah kepada perbaikan proses dalam menghasilkan kualitas yang ditandai dengan belajar yang efektif yang membawa perubahan pada kemampuan pemelajar sehingga dapat mengaplikasikan ilmunya dalam dunia nyata. Kementerian Pendidikan Nasional (2008) mengatakan bahwa perbaikan proses dalam hubungannya dengan kinerja guru terdiri atas tugas dan profesi guru seperti (1) rencana pembelajaran (teaching plans and materials) atau disebut dengann RPP (Rencana Pelaksanaan Pembela-jaran), (2) prosedur pembelajaran (classroom procedure), dan (3) hubungan antar pribadi (interpersonal skill).

Pelatihan dapat dipandang sebagai proses yang langsung terikat dengan hasil-hasil yang spesifik yang fokusnya pada perbaikan individu, kelompok, dan organisasi (Schneider, 1985). Pelatihan juga dipandang sebagai suatu proses belajar tentang urutan perilaku terprogram, merupakan aplikasi pengetahuan dan memberikan kesadaran kepada orang tentang aturan dan prosedur untuk mengarahkan prilaku, membantu untuk membawa perubahan positif pada pengetahuan, keterampilan dan sikap, suatu proses memperbaiki keterampilan dan menambah pengetahuan yang sudah ada sehingga mampu melakukan pekerjaan dan membentuk peserta didik untuk menyelesaikan pekerjaan yang lebih besar yang melibatkan tanggungjawab yang besar pula, dan menjembatani kesenjangan antara apa yang dimiliki guru dengan tuntutan kerja (Dinkelmann, Riffelmacher, \& Westkämper,
2012). Pelatihan adalah bantuan atau bimbingan yang diberikan untuk orang perorang dalam menciptakan transisi pengetahuan, berpikir atau bekerja yang berguna (Allen, Eby, \& Lentz, 2006).

Desain (perancangan) merupakan proses menspesifikasi kondisi belajar, design is process of specifying conditions for learning (Seels \& Richey, 2012: 30). Desain juga, dipandang sebagai proses untuk menghasilkan rencana atau blueprint dalam upaya mengembangkan materi yang menunjang pembelajaran (Gagne, Wager, Golas, and Keller, 2005). The design component of the instructional systems design process results in a plan or blueprint for guiding the development of instruction (Gagne, Wager, Golas, Keller, \& Russell, 2005: 26). Maksudnya, komponen desain dalam proses desain sistem pembelajaran menghasilkan rencana atau blueprint (cetak biru) untuk mengarahkan pengembangan pembelajaran (Yaumi, 2016b). Dengan demikian yang dimaksud dengan desain adalah suatu proses menyusun persiapan untuk menentukan kondisi belajar.

Selanjutnya, pendampingan (mentor) adalah individu yang peduli, bersama dengan orang tua atau wali, menyediakan orang-orang muda dengan memberikan dukungan, nasihat, penguatan persahabatan, dan contoh yang konstruktif. Yaumi (2014) cenderung memandang bahwa kegiatan pendampingan berhubungan langsung dengan umur, paling tidak dilakukan oleh senior kepada yuniornya. Namun, jika merujuk pada konsep the skill-will matrix (Hawkins, 2009) di mana proses pendampingan hanya dilihat dari keterampilan (skill) dan kemauan (will) untuk menyelesaikan 
tugas, maka umur bukanlah menjadi ukuran dalam pelaksanaan kegiatan pendampingan.

Pembelajaran adalah sistem pendidikan dalam menfasilitasi peserta didik untuk menjadi agen perubahan melalui pengalaman, pengetahuan, keterampilan, dan kemampuan yang dilakukannya sendiri serta memperoleh metode untuk belajar mandiri (Kozulin, Gindis, Ageyev, \& Miller, 2003; Agudo-Peregrina, Iglesias-Pradas, Conde-González, \& HernándezGarcía, 2014). Sedangkan, yang dimaksud dengan kecerdasan jamak adalah kemampuan atau talenta yang dimilki oleh seseorang yang mencakup (1) kecerdasan verbal-linguistik, (2) logis-matematik, (3) visual-spatial, (4) musikberirama, (5) jasmaniah-kinetetik, (6) interpersonal, (7) intrapersonal, (8) naturalistik (Gardner, 2000), dan (9) kecerdasan spiritual (McKenzie, 2005), atau eksistensial (Bowles, 2008), atau dalam hal ini penulis sebut sebagai kecerdasan eksistensial-spiritual.

Kecerdasan verbal linguistik. Bahasa merupakan salah satu alat komunikasi yang sangat penting dalam kehidupan manusia (Ibrahim \& Yaumi, 2016). Dalam kehidupan anak-anak, peranan bahasa menjadi sangat vital dalam upaya mencerdaskan kehidupan anak, bahkan bahasa dipandang sebagai aktivitas sosial sebagai-mana anak-anak menggunakan keterampilannya untuk mem-bangun persahabatan, komp-romi, negosiasi, dan menyelesaikan masalah yang dihadapi (Sonowat \& Gogri, 2008). Kecerdasan logis-matematis adalah kemampuan yang berkenaan dengan rangkaian alasan, mengenal pola-pola dan aturan (Li, Ma, \& Ma, 2012). Kecerdasan ini merujuk pada kemampuan untuk mengeksplorasi pola- pola, kategori-kategori dan hubungan dengan memanipulasi objek atau simbol untuk melakukan percobaan dengan cara yang terkontrol dan teratur (Kezar, 2001).

\section{Kecerdasan berirama musik adalah} adalah kapasitas berpikir dalam musik untuk mampu mendengarkan pola-pola dan mengenalnya serta dapat memanipulasinya (Snyder, 1997). Kecerdasan JasmaniahKinestetik adalah kemampuan untuk menggunakan seluruh tubuh untuk mengekspresikan ide dan perasaan, serta menggunakan tangan untuk menghasilkan atau mentransformasi sesuatu. Kecerdasan ini mencakup keterampilan khusus seperti, koordinasi, keseimbangan, ketangkasan, kekuatan, fleksibilitas dan kecepatan (Tracey \& Richey, 2007). Kecerdasan Visual-Spasial atau kecerdasan gambar atau kecerdasan pandang ruang didefinisikan sebagai kemampuan mempresepsi dunia visual-spasial secara akurat serta men-transformasikan persepsi visual-spasial tersebut dalam berbagai bentuk (Li et al., 2012). Kemampuan berpikir Visual Spasial merupakan ke-mampuan berpikir dalam bentuk visualisasi, gambar dan bentuk tiga dimensi (Rettig, 2005).

Kecerdasan interpersonal di-definisikan sebagai kemampuan mempersepsi dan membedakan suasana hati, maksud, motivasi dan keinginan orang lain, serta kemampuan memberikan respons secara tepat terhadap suasana hati, temperamen, motivasi dan keinginan orang lain. Kecerdasan intrapersonal adalah kemampuan memahami diri sendiri dan bertindak berdasarkan pemahaman tersebut. Komponen inti dari Kecerdasan Intrapersonal kemampuan memahami diri yang akurat meliputi 
kekuatan dan keterbatasan diri, kecerdasan akan suasana hati, maksud, motivasi, temperamen dan keinginan, serta kemampuan berdisiplin diri, memahami dan menghargai diri. Kecerdasan naturalistik didefinisikan sebagai keahlian mengenali dan mengategorikan spesies, baik flora maupun fauna, di lingkungan sekitar, dan kemampuannya mengolah dan memanfaatkan alam, serta melestarikannya. Komponen inti kecerdasan naturalistik adalah kepekaan terhadap alam (flora, fauna, formasi awan, gununggunung), keahlian membedakan anggota-anggota suatu spesies, mengenali eksistensi spesies lain, dan memetakan hubungan antara beberapa spesies baik secara formal maupun informal.

Terakhir adalah kecerdasan eksistensialspiritual yang diya-kini sebagai kecerdasan yang paling esensial dalam kehidupan manusia dibandingkan dengan berbagai jenis kecerdasan lain seperti kecerdasan intelektual, emosional, dan kecerdasan sosial. Kecerdasan spiritual itu bersandar pada hati dan terilhami sehingga jika seseorang memiliki kecerdasan spiritual, maka segala sesuatu yang dilakukan akan berakhir dengan sesuatu yang menyenangkan (Zohar \& Marshall, 2001).

\section{METODOLOGI PENELITIAN}

Metode penelitian ini adalah penelitian tindakan (action research), yaitu metode penelitian yang menekankan pada praktik sosial, bertujuan ke arah peningkatan, suatu proses siklus, diikuti dengan penemuan yang sistematis, proses reflektif, bersifat partisipatif, dan ditentukan oleh pelaksana (Kamber, 2000). Jenis penelitian tindakan ini termasuk penelitian tindakan praktis dan berada pada tingkat madrasah (school-wide) (Schmuck, 2006). Penelitian ini menggunakan model Elliott dengan sedikit modifikasi, khususnya reconnaissance (pemeriksaan) yang dimodifikasi menjadi evaluasi. Desain penelitian ini dilakukan dengan beberapa siklus dan setiap siklus dimulai dengan beberapa tahap seperti (1) rencana umum tindakan, (2) implementasi, (3) mengawasi implementasi dan dampak, dan (4) evaluasi (Yaumi, 2016). Sebelum membuat rencana umum tindakan pada siklus pertama dilakukan identifikasi gagasan awal, temuan dan analisis fakta (Elliot, 1991).

Penelitian ini dilakukan melalui tiga tahap atau siklus; siklus pertama, peneliti berkolaborasi dengan pengawas dan kepala sekolah dalam memberikan pelatihan tentang pembelajaran berorientasi pada peserta didik berbasis kecerdasan jamak yang orientasinya pada pema-haman konsep, strategi, prosedur, media, contoh-contoh dan berbagai bentuk penilaian berbasis pada keberagaman peserta didik. Siklus kedua, memberikan workshop yang berkaitan dengan desain aktivitas pembelajaran berorientasi peserta didik berbasis kecerdasan jamak. Produk dari workshop menghasilkan ragam aktivitas pembelajaran yang beroeintasi pada pengembangan pengetahuan, sikap, dan kete-rampilan peserta didik. Siklus ketiga, peneliti, pengawas, dan kepala sekolah fokus pada pengampingan guru dalam pelaksanaan pembelajaran. Di sisi peneliti dan kolaborator menga-mati seluruh rangkaian pembelajaran yang diikuti dengan pemberian petunjuk, arahan, dan contoh-contoh yang berkenaan langsung dengan penerapan aktivitas pembelajaran berorientasi pengembangan kecerdasan peserta 
didik.

Penelitian ini dilakukan kepada 26 orang guru Madrasah Ibtidaiyah yang berasal dari sepuluh (10) sekolah di Kabupaten Gowa Sulawesi Selatan dengan melibatkan unsur kepala sekolah, komite sekolah, dewan pendidikan, dan Dinas pendidikan sebagai kolaborator. Teknik pengumpulan data dalam penelitian ini, yaitu observasi, wawancara, dan tes.

Data dianalisis secara kualitatif dan data kuantitatif. Analisis data kualititatif dilakukan dengan menggunakan model interaktif yang dikembangkan Miles, Huberman, dan Saldana yaitu kondensasi data, penyajian, verifikasi, dan penarikan kesimpulan (Miles, Huberman, \& Saldana, 2013). Data kuantitatif dihitung berdasarkan kriteria penilaian yang mencakup tidak memenuhi standard $=1$, di bawah standard $=2$, memenuhi standard $=3$, dan di atas standard $=4$ dihitung dengan menggunakan analisis kuantitatif baik untuk mencari skor rata-rata (mean) maupun untuk menghitung skor persentase responden yang mendapat skor tertentu. Keberhasilan dari kinerja dalam penelitian tindakan ini adalah apabila terdapat sembilan puluh (90) persen responden yang telah mencapai "memenuhi standar atau di atas standar.”

\section{HASIL DAN PEMBAHASAN}

\section{Pra-siklus}

Pada tahap ini peneliti bersama dengan supervisor dan kepala sekolah melakukan observasi terhadap pelaksanaan pembelajaran dengan menggunakan sembilan peristiwa belajar Gagne yang dibagi ke dalam tiga kegiatan: kegiatan awal, tengah, dan akhir.

Tabel 1. Kondisi Awal Kinerja Guru

\begin{tabular}{|c|c|c|c|c|}
\hline KEGIATAN & \multicolumn{4}{|c|}{$\begin{array}{c}\text { INFORMAN YANG } \\
\text { DIOBERVASI }\end{array}$} \\
\hline KEGIATAN AWAL & 1 & 2 & 3 & 4 \\
\hline Menarik Perhatian & - & 15 & 9 & 2 \\
\hline Apersepsi & 3 & 9 & 10 & 4 \\
\hline Menyampaikan Tujuan & - & 10 & 14 & 2 \\
\hline \multicolumn{5}{|l|}{ KEGIATAN TENGAH } \\
\hline Memberi Stimulus & 4 & 6 & 16 & - \\
\hline Menyediakan Petunjuk Belajar & 6 & 7 & 10 & 3 \\
\hline $\begin{array}{l}\text { Mengidentifikasi kinerja peserta } \\
\text { didik dalam belajar }\end{array}$ & 7 & 10 & 8 & 1 \\
\hline \multicolumn{5}{|l|}{ KEGIATAN AKHIR } \\
\hline Memberikan Umpan Balik & - & 4 & 11 & 1 \\
\hline Mengukur Kinerja Peserta Didik & - & 12 & 8 & 6 \\
\hline $\begin{array}{l}\text { Meningkatkan Daya Ingat Peserta } \\
\text { Didik }\end{array}$ & 8 & 12 & 4 & 2 \\
\hline
\end{tabular}

Kondisi awal kinerja guru berdasarkan tabel 1 di atas dapat dibagi ke dalam dua dari empat kriteria; Kinerja di bawah Standar dan di atas Standar. Pada kegiatan awal, data menunjukkan bahwa bahwa terdapat $47,44 \%$ informan memiliki kinerja di bawah standar dan $52,56 \%$ yang memiliki kinerja di atas standar.

Pada kegiatan tengah, terdapat terdapat $51,28 \%$ yang memiliki kinerja di bawah standar dan hanya $48,72 \%$ yang memiliki kinerja di atas standar. Adapun pada kegiatan akhir, data menunjukkan bahwa terdapat $46,15 \%$ berada di bawah standar dan 41,02\% menunjukkan kinerja berada di atas standar.

\section{Siklus Pertama}

Setelah diberi pelatihan tentang pembelajaran berbasis kecerdasan jamak selama 3 hari, di mana informan mendapatkan pemahaman tentang keragaman peserta didik, strategi pembelajaran, dan model penilaian yang mengakomodasi peserta didik berdasarkan keragaman kecerdasan dan gaya belajar, maka ditemukan hasil yang baik. 
Untuk memperoleh data tentang hasil pelaksanaan penelitian, diberikan tes yang dilanjutkan dengan observasi terhadap kinerja guru dalam pelaksanaan pembelajaran di ruang kelas. Berdasarkan hasil pre-test dan post-test, dapat dilihat bahwa kinerja guru dalam hubungannya dengan pemahaman konsep, teori, dan strategi pembelajaran berorientasi dan berpusat pada peserta didik menunjukkan peningkatan yang signifikan seperti dijabarkan dalam gambar berikut:

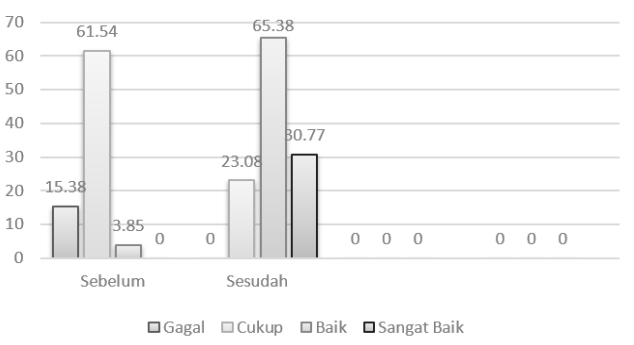

Gambar 1. Perbandingan Pre-test \& Post-test

Gambar tersebut menunjukkan bahwa tingkat terendah yang dicapai oleh responden sebelum dilaksanakan pelatihan adalah tingkat gagal, sedangkan setelah dilaksanakan pelatihan adalah tingkat cukup yang hanya dicapai oleh 1 (3, 85\%) responden. Selain itu, tingkat kurang merupakan pencapaian skor mayorits responden sebelum dilaksanakan pelatihan, sedangkan tingkat baik adalah skor terbanyak setelah dilaksakan pelatihan. Kemudian, pencapaian skor yang paling tinggi yang diperoleh responden sebelum pelaksanaan pelatihan adalah tingkat kurang (atau tingkat terendah setelah pelatihan), sedangkan sesudah pelaksanaan pelatihan pencapaian skor ter-tinggi adalah pada tingkat baik sekali.

\section{Kontribusi Pelatihan terhadap Peningkatan Kinerja Guru}

Dibandingkan dengan skor awal atau sebelum dilaksanakan pelatihan tentang pembelajaran berbasis kecerdasan jamak, maka diperoleh kenaikan sebesar $54,61 \%$ untuk aktivitas awal, 19,22\% untuk aktivitas tengah eksplorasi, $21,87 \%$ untuk ke-giatan tengah elaborasi, dan sebanyak $34,72 \%$ untuk aktivitas konfirmasi dan kegiatan tindak lanjut (penutup) Peningkatan ini terjadi menunjukkan adanya kontribusi pelatihan dalam perbaikan kinerja guru. Untuk melihat perbandingan antara kenaikan kinerja sebelum dan sesudah diberikan pelatihan dapat digambarkan dalam persentase sebagai berikut:

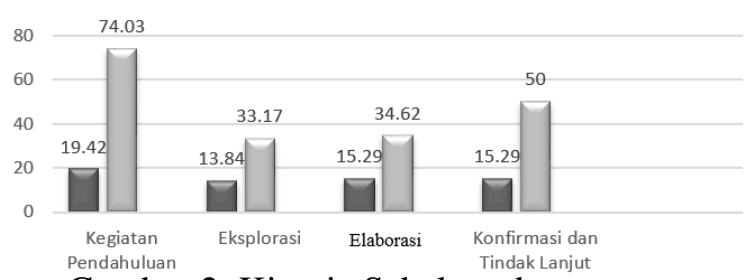

Gambar 2. Kinerja Sebelum dan

Gambar 2 tersebut memperlihatkan bahwa implementasi pelatihan tentang pembelajaran berbasis kecerdasan jamak telah dapat meningkatkan pemahaman guru tentang proses pembelajaran khususnya aktivitas pembelajaran dan memberikan dampak pada peningkatan kinerja guru dalam pelaksanaan pembelajaran, di mana kontribusi pelatihan telah menghasilkan kenaikan rata-rata sebesar 32, $61 \%$ responden berada pada tingkat memenuhi standar kinerja. Namun demikian, kenaikan tersebut belum sesuai dengan standar peningkatan kinerja seperti yang diinginkan dalam penelitian ini. 


\section{Siklus Kedua}

\section{Desain Aktivitas Pembelajaran Berbasis Kecerdasan Jamak}

Berdasarkan analisis hasil wawancara dengan responden tentang aktivitas pembelajaran yang sesuai dengan kebutuhan madrasah Ibtidaiyah dan komponen-komponen yang diintegrasikan dalam aktivitas tersebut dapat diuraikan berikut; a) kecerdasan verbal-linguistik adalah meminta sumbang saran, mengadakan storytelling (bercerita atau mendongeng), menulis jurnal, dan membaca biografi (sebaiknya tokoh lokal); b) kecerdasan logismatematik adalah menerapkan model berpikir kritis, bereksperimen, mengajukan pertanyaan model Socrates, menerapkan problem solving (penyelesaian masalah); c) kecerdasan visual-spasial adalah membuat potongan kertas berwarna-warni, mewarnai gambar, membuat sketsa; d) kecerdasan jasmaniah kinestetik adalah studi lapangan, bermain peran, berpantomim, dan menyelidiki bagian-bagian benda, menggunakan bagian-bagian tubuh dalam menulis untuk kelas-kelas rendah; e) kecerdasan berirama musik adalah diskografi, musik instrumen, serta bunyi dan orang, bentuk bunyi untuk kelas-kelas rendah; f) kecerdasan interpersonal adalah melakukan aktivitas jig-saw, mengajar teman sebaya, dan membuat teamwork (kerja tim); g) kecerdasan intrapersonal seperti melakukan tugas mandiri, melakukan refleksi, menetapkan tujuan, menunjukkan bentuk aktivitas, mengungkapkan perasaan, membuat identifikasi; h) kecerdasan naturalistik seperti belajar melalui alam, jendela belajar, menggunakan tanaman sebagai alat dan media, memelihara binatang dalam ruang kelas, meniru bunyi-bunyi binatang; j) kecerdasan eksistensial-spiritual seperti memberi respon pada suatu peristiwa dan membuat panggung beramal.

Adapun Komponen-komponen yang perlu diintegrasikan dalam mendesain model aktivitas pembelajaran berbasis kecerdasan jamak adalah (1) pengantar, (2) definisi, konsep, atau teori, (3) tujuan, (4) prosedur, dan (5) alat atau bahan yang dibutuhkan dalam proses pelaksanaan aktivitas. Setelah mendesain aktivitas pembelajaran, kemudian diadakan penjelasan teknik tentang penerapannya melalui workshop sehari, kemudian menerapkan langsung dalam pelaksanaan pembelajaran.

\section{Kontribusi Desain terhadap Peningkatan Kinerja Guru}

Jabaran kinerja guru pada setiap siklus dapat dilihat pada gambar berikut:

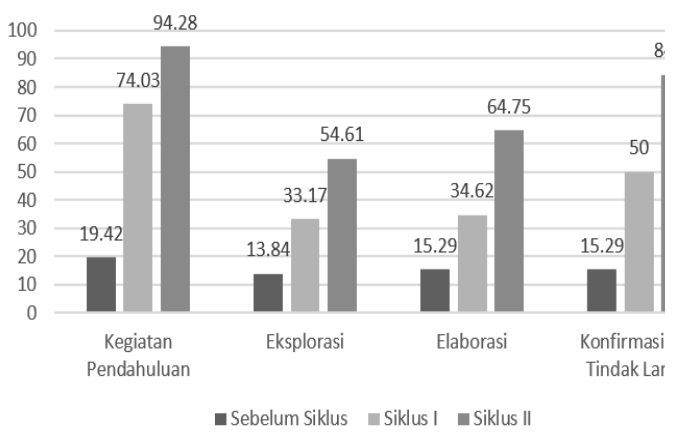

Gambar 3. Kinerja Guru setelah Mendesain 
Gambar 3 tersebut menunjukkan kecenderungan peningkatan kinerja pada siklus kedua. Pada gambar tersebut dijabarkan secara bersama-sama kinerja pada pengamatan awal, siklus pertama dan siklus kedua. Data yang ditunjukkan pada gambar bahwa rata-rata kontribusi desain model aktivitas pembelajaran berbasis kecerdasan jamak menghasilkan kenaikan rata-rata sebesar $26,55 \%$ responden berada pada tingkat memenuhi standar kinerja. Artinya terdapat kontribusi positif pelaksanaan workshop tentang aktivitas pembelajaran berorienta-si peserta didik. Sekalipun demikian, peningkatan kinerja guru berdasarkan hasil observasi terhadap responden sampai pada siklus kedua ini belum mencapai $90 \%$ responden yang berada pada tingkat memenuhi standar. Oleh karena itu, perlu dilanjutkan dengan tindakan pada siklus berikutnya.

\section{Siklus Ketiga}

\section{Kontribusi Pendampingan terhadap Peningkatan Kinerja}

Sebelum dilakukan pendampingan (mentoring), terlebih dahulu melakukan identifikasi keterampilan dan kemauan yang dimiliki responden dengan maksud untuk menentukan model pendampingan yang sesuai dengan kebutuhan responden. Identifikasi keterampilan kemauan menggunakan matriks Max Lendsberg (Serrat, 2017).

Analisis tentang keterampilan dan kemamuan menunjukkan bahwa terdapat 2 $(7,69 \%)$ responden memiliki keterampilan rendah dan kemauan rendah dalam kaitannya dengan membuat atau merancang tugas yang sesuai dengan aktivitas pembelajaran berbasis kecerdasan jamak dan pendampingan yang dilakukan adalah menunjukkan atau mengarahkan (direct). Hal ini didasarkan pada model skema pendampingan yang terdapat pada Max Lendsberg seperti dijelaskan di atas.

Berdasarkan skema, sebanyak 13 (50\%) responden yang memiliki keterampilan rendah tapi kemauan tinggi dan kepada mereka diberikan pendampingan menuntun (guide). Sebanyak $3(11,54 \%)$ responden mempunyai keterampilan tinggi tapi kemauaan rendah dan bagi mereka diberikan pendampingan mendorong atau membuat gembira (excite), dan sebanyak $8 \quad(30,77 \%)$ responden mempunyai keterampilan tinggi dan kemauan tinggi, bagi mereka diberikan pendampingan cukup dengan mendelegasikan (delegate). Hasil identifikasi tersebut lebih jelasnya digambarkan sebagai berikut:

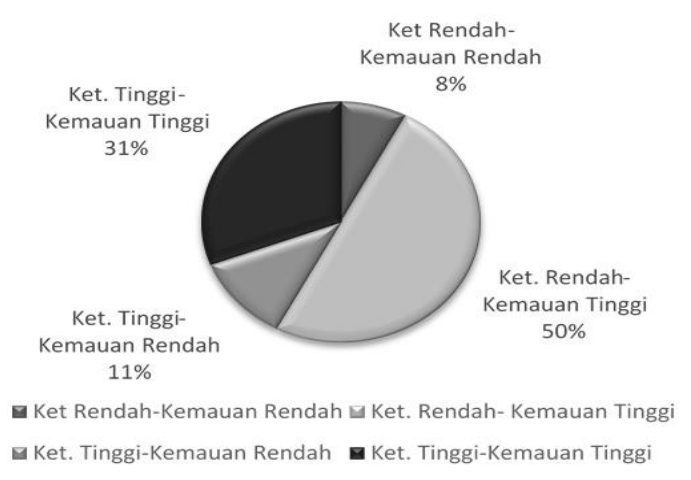

\section{Gambar 4. Hasil Identifikasi Keterampilan \& Kemauan sebelum Diberi Pendampingan}

Berdasarkan kriteria dari hasil analisis terhadap keterampilan dan kemauan tersebut, maka pendampingan yang dilakukan dalam penelitian ini lebih banyak menggunakan strategi membimbing (keterampilan rendah, kemauan tinggi) dengan pendampingan tradisional satu 
persatu di mana peneliti memberikan waktu sebanyak mungkin untuk melakukan pelatihan, pembinaan, menjelaskan, dan menjawab pertanyaan.

\section{Persepsi tentang Pembelajaran}

Setelah melakukan pendampingan terhadap penerapan aktivitas pembelajaran berbasis kecerdasan jamak, kemudian mewawancarai kepala sekolah, pengawas, komite sekolah dan peserta didik, maka pembelajaran yang dilakukan oleh guru mencerminkan Pertama, pembelajaran menyenangkan (1) didesain dengan memperhatikan kebutuhan peserta didik, (2) melibatkan peserta didik untuk mencari sumber belajar sendiri, (3) menggunakan media dan teknologi, (4) perpaduan antara penguasaan teori di kelas dan praktik di lapangan (5) penggunaan seluruh anggota tubuh atau panca indera untuk menjadi pintu masuk ilmu pengetahuan, mengintegrasikan musik dalam pembelajaran. Kedua, pembelajaran aktif yang berbasis pada tugas. Ketiga, pembelajaran kooperatif (1) melibatkan banyak orang, (2) pemanfaatan berbagai sumber, dan (3) dilakukan dengan pembimbingan, (4) belajar dengan teman sejawat jauh lebih memberikan dampak yang lebih besar dari pada dengan guru. Keempat, pembelajaran menarik (1) mengintegrasikan bermain peran, (2) berbasis muatan lokal, (3) berbasis pada masyarakat, (4) bertujuan untuk mengubah keadaan, (5) adanya petunjuk-petunjuk kerja yang jelas (6) memberikan kemerdekaan dan kewenangan kepada peserta didik. Kelima, pembelajaran dapat me-motivasi peserta didik ketika apa yang dipelajari dihubungkan dengan keadaan di sekitar dan secara internal berkenaan dengan perasaan. Keenam, kepuasan dalam belajar (1) ketika mampu didemonstrasikan, (2) memanfaatan alam sebagai sumber belajar, (3) membantu dan menggerakkan masyarakat.

\section{Kontribusi Pendampingan terhadap Peningkatan Kinerja Guru}

Setelah melakukan identifikasi keterampilan kemauan, memberikan pendampingan kepada responden dalam menerapkan aktivitas pembelajaran berbasis kecerdasan jamak, dan mengukur mengamati tentang kondisi kinerja guru, maka diperoleh kecenderungan peningkatan kinerja yang dapat digambarkan dengan membandingkan langsung peningkatan dari pengamatan awal, siklus pertama, siklus kedua, dan siklus ketiga, seperti berikut ini.

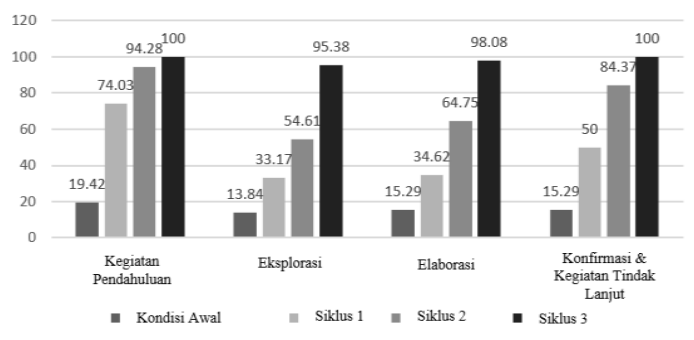

Gambar 5. Peningkatan Kinerja dari Siklus ke Siklus

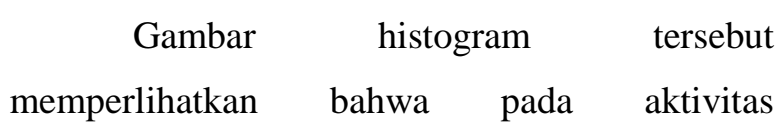
pendahuluan jumlah responden yang berada pada 
tingkat memenuhi standar sebanyak $19,42 \%$ pada pengamatan awal, naik menjadi $74,03 \%$ pada siklus pertama, meningkat menjadi $94.28 \%$ pada siklus kedua, dan menjadi $100 \%$ pada siklus ketiga. Pada kegiatan inti eksplorasi menunjukkan bahwa terdapat sebanyak 13,84\% pada pengamatan awal, meningkat menjadi $33,17 \%$ pada siklus pertama, meningkat menjadi $54,61 \%$ pada siklus kedua, dan menjadi $95,38 \%$ pada siklus ketiga. Dalam aktivitas inti elaborasi menunjukkan sebanyak $15,29 \%$ pada pengamatan awal, sebanyak $34,62 \%$ pada siklus pertama, meningkat menjadi $64,75 \%$ pada siklus kedua, dan meningkat menjadi $98,08 \%$ pada siklus ketiga. Dalam aktivitas penutup terdapat sebanyak $15,29 \%$ untuk pengamatan awal, meningkat menjadi $50 \%$ pada siklus pertama, menjadi $84,37 \%$ pada siklus kedua, dan meningkat menjadi $100 \%$ pada siklus ketiga. Rata-rata responden yang sudah berada pada tingkat memenuhi standar dan di atas standar sebanyak 98, 37\%. Artinya, kontribusi pelaksanaan pelatihan, desain aktivitas, dan penerapan aktivitas pembelajaran berbasis kecerdasan jamak telah berhasil meningkatkan kinerja guru dalam pelaksanaan pembelajaran. Dengan demikian, peningkatan kinerja responden sampai pada siklus ketiga telah melampaui total target sebanyak $90 \%$ responden yang berada pada tingkat memenuhi dan di atas standar. Oleh karena itu, siklus berikutnya tidak dibutuhkan lagi atau pelaksanaan tindakan berhenti pada siklus ketiga.

\section{PENUTUP}

Berdasarkan hasil dan pembahasan di atas, maka dapat ditarik kesimpulan sebagai berikut:

Pertama: kinerja guru Madrasah Ibtidaiyah di Kabupaten Gowa Sulawesi Selatan sebelum dilaksanakan pelatihan, desain, dan pendampingan berada pada kategori cukup baik, terdapat $85,43 \%$ guru Madrasah Ibtidaiyah belum memenuhi standar kinerja atau rata-rata 15,33\% yang memenuhi standar kinerja. Mereka dominan $(86,62 \%)$ menggunakan pendekatan yang berpusat pada guru dan terdapat hanya 16, 67\% yang menggunakan pembelajaran berbasis pada peserta didik. Pelaksanaan pelatihan tentang pembelajaran berbasis kecerdasan jamak pada siklus pertama terbukti mampu meningkatan pemahaman guru tentang pembelajaran berbasis pada peserta didik dan memberi kontribusi positif (rata-rata sebesar $32,61 \%$ ) pada peningkatan kinerja dalam pembelajaran. Mayoritas guru perpendapat bahwa pembelajaran berbasis kecerdasan jamak sangat menarik untuk diterapkan di madrasah karena sangat efektif dalam memahami keberagaman pe-serta didik, perkembangan intelektual dan pengetahuan teknik peserta didik dan dapat mengukur tingkat ketercapaian tujuan berdasarkan karak-teristik peserta didik.

Kedua: desain pembelajaran berbasis kecerdasan jamak pada siklus kedua dilakukan melalui model workshop untuk menghasilkan produk yang berkenaan dengan aktivitas pembelajaran. Produk yang dimaksud mencakup tiga puluh empat (34) aktivitas pembelajaran termasuk penje-lasan-penjelasan yang terdiri atas lima komponen termasuk (1) pengantar, (2) definisi, konsep, atau teori, (3) tujuan, (4) prosedur, dan (5) alat atau bahan yang dibutuhkan dalam proses pelaksanaan masing- 
masing aktivitas pembelajaran. Aktivitas tersebut disesuaikan dengan jenis kecerdasan peserta didik. Setelah aktivitas pembelajaran didesain terbukti memberi kontribusi rata-rata $26,55 \%$ pada peningkatan kinerja guru dalam melaksanakan pembelajaran.

Ketiga: pelaksanaan pendampingan pada siklus ketiga diawali dengan identifikasi keterampilan dan kemauan guru Madrasah Ibtidaiyah di Kabupaten Gowa Sulawesi Selatan. Hasil identifikasi menunjukkan bahwa terdapat (50\%) guru memiliki kemampuan rendah dan kemauan yang tinggi. Dengan demikian, jenis pendampingan yang dilakukan adalah membimbing yang merujuk pada pendampingan tradisional dengan model satu persatu atau satu informan didampingi oleh satu pembimbing. Pelaksanaan pendampingan terbukti memberi kontribusi (rata-rata 23,86\%) pada peningkatan kinerja guru dalam melak-sanakan pembelajaran.

\section{DAFTAR PUSTAKA}

Agudo-Peregrina, Á. F., Iglesias-Pradas, S., Conde-González, M. Á., \& HernándezGarcía, Á. (2014). Can we predict success from log data in VLEs? Classification of interactions for learning analytics and their relation with performance in VLE-supported F2F and online learning. Computers in Human Behavior, 31, 542-550

Allen, T. D., Eby, L. T., \& Lentz, E. (2006). Mentorship behaviors and mentorship quality associated with formal mentoring programs: closing the gap between research and practice. Journal of Applied Psychology, 91(3), 567.
Bowles, T. (2008). Self-rated Estimates of Multiple Intelligences Based on Approaches to Learning. Australian Journal of Educational \& Developmental Psychology, 8, 15-26.

Dinkelmann, M., Riffelmacher, P., \& Westkämper, E. (2012). Training concept and structure of the Learning Factory advanced Industrial Engineering. In Enabling Manufacturing Competitiveness and Economic Sustainability (pp. 623-629). Springer.

Elliot, J. (1991). Action research for educational change. McGraw-Hill Education (UK).

Gagne, R. M., Wager, W. W., Golas, K. C., Keller, J. M., \& Russell, J. D. (2005). Principles of instructional design. Performance Improvement, 44(2), 4446.

Gardner, H. (2000). Intelligence reframed: Multiple intelligences for the 21st century. Hachette UK.

Harris, D. N., \& Sass, T. R. (2011). Teacher training, teacher quality and student achievement. Journal of Public Economics, 95(7), 798-812.

Hawkins, P. (2009). Coaching supervision. 2009). The Complete Handbook of Coaching, 394.

Hotimah, H. (2017). Strategi Pendidikan Profesi Guru (PPG) UNESA Dalam Mengembangkan Kompetensi Pedagogik dan Profesional Peserta PPGPasca SM3T. Kajian Moral Dan Kewarganegaraan, 5(1).

Hurmaini, M. (2011). Dampak pelaksanaan 
sertifikasi guru terhadap peningkatan kinerja guru dalam proses pembelajaran: Studi pada Madrasah Tsanawiyah Negeri Kota Jambi. Media Akademika, 26(4).

Ibrahim, Y., \& Yaumi, M. (2016). PembelajaranBerbasisKecerdasanJamak (Multiple Intelligences): Mengidentifikasi dan Mengembangkan Multitalenta Anak. Jakarta: Kencana.

Ismail, A., Abdullah, M. M., \& Francis, S. K. (2009). Mentoring program and its impact on individuals' advancement in the Malaysian context. Journal of Industrial Engineering and Management-Vol 2, No 3 (2009).

Januszewski, A., \& Molenda, M. (2013). Educational technology: A definition with commentary. Routledge.

Kamber, D. (2000). Action Learning Research Improving the Quality of Teaching and Learning. London: Page Limited.

Kementerian Pendidikan Nasional. (2008). Penilaian Kinerja Guru. Jakarta: Direktoral Jenderal Peningkatan Mutu Pendidik dan Tenaga Kependidikan Departemen Pendidikan Nasional.

Kezar, A. (2001). Theory of multiple intelligences: Implications for higher education. Innovative Higher Education, 26(2), 141-154.

Khodijah, N. (2016). Kinerja guru madrasah dan guru pendidikan agama Islam pasca sertifikasi di Sumatera Selatan. Jurnal Cakrawala Pendidikan, 5(1).

Kozulin, A., Gindis, B., Ageyev, V. S., \& Miller, S. M. (2003). Vygotsky's educational theory in cultural context. Cambridge University Press.

Li, J., Ma, S., \& Ma, L. (2012). the study on the effect of educational games for the development of students' logicmathematics of multiple intelligence. Physics Procedia, 33, 1749-1752.

McKenzie, W. (2005). Multiple intelligences and instructional technology. ISTE (Interntl Soc Tech Educ.

Miles, M. B., Huberman, A. M., \& Saldana, J. (2013). Qualitative data analysis. Sage.

Rettig, M. (2005). Using the multiple intelligences to enhance instruction for young children and young children with disabilities. Early Childhood Education Journal, 32(4), 255-259.

Schmuck, R. A. (2006). Practical action research for change. Corwin Press.

Schneider, W. (1985). Training highperformance skills: Fallacies and guidelines. Human Factors, 27(3), 285300.

Seels, B. B., \& Richey, R. C. (2012). Instructional technology: The definition and domains of the field. IAP.

Serrat, O. (2017). Coaching and mentoring. In Knowledge Solutions (pp. 897-902). Springer.

Snyder, S. (1997). Developing musical intelligence: Why and how. Early Childhood Education Journal, 24(3), 165-171.

Sonowat, R., \& Gogri, P. (2008). Multiple Intelligences For Preschool Children. Mumbai: Multi-Tech Publishing Co. 
Taruna, M. M. (2011). Kompetensi Guru Pendidikan Agama Islam. Analisa: Journal of Social Science and Religion, 18(2), 180-196.

Tracey, M. W., \& Richey, R. C. (2007). ID model construction and validation: A multiple intelligences case. Educational Technology Research and Development, 55(4), 369-390.

Yaumi, M. (2014). Model Perbaikan Kinerja Guru dalam Pembelajaran. Makassar: Makassar: Alauddin Press.
Yaumi, M. (2016a). Action Research: Teori, model dan aplikasinya. Retrieved from https://books.google.co.id/books?id=XIuDwAAQBAJ

Yaumi, M. (2016b). Prinsip-prinsip desain pembelajaran. Kencana Prenada Media Group.

Zohar, D., \& Marshall, I. (2001). SQ: memanfaatkan kecerdasan spiritual dalam berpikir| integralistik aan holistik untuk memaknai kehidupan. Mizan. 